\title{
Central Line-associated Pantoea spp. Bacteremia and Solid Organ Malignancy: A Report of Two Cases
}

\author{
Santral Kateter Iliş̧ili Pantoea spp. Bakteriyemisi ve Solid Organ Malignitesi: Iki Olgu \\ Sunumu
}

\author{
(1) Esra ÖZSOY KAYAOKAY1 , (1) Gülcan BULUT2 2 , (1) Şöhret AYDEMIR³, (1) Rüçhan USLU2, (1) Oğuz Reşat SiPAHi4 \\ ${ }^{1}$ Ege University Faculty of Medicine, Department of Internal Medicine, Izmir, Turkey \\ 2Ege University Faculty of Medicine, Tülay Aktaş Oncology Hospital, Department of Medical Oncology, Izmir, Turkey \\ ${ }^{3}$ Ege University Faculty of Medicine, Department of Medical Microbiology, Izmir, Turkey \\ ${ }^{4}$ Ege University Faculty of Medicine, Department of Infectious Diseases and Clinical Microbiology, Izmir, Turkey
}

Keywords: Pantoea spp., central line bacteremia, Pantoea dispersa, ceftriaxone

Anahtar Kelimeler: Pantoea spp., santral kateter bakteriyemisi, Pantoea dispersa, seftriakson

Dear Editor,

Pantoea spp., are facultative anaerobic Gram-negative bacilli that are members of the Enterobacteriaceae family. Pantoea spp. are known as etiologic agents of plant diseases. These opportunistic-pathogen bacteria may colonize the skin and respiratory, urinary and gastrointestinal systems while these regions serve as entrance for the disease. Pantoea spp., (most frequently $P$. agglomerans) may cause septic arthritis, pneumonia, sepsis, peritonitis, urinary tract infection, surgical site infections, and catheter-related nosocomial infections ${ }^{[1]}$. Herein, we report two cases of catheter-related Pantoea spp. blood stream infections (CRBSI).

A 56-year-old female patient who was investigated for urticaria etiology was diagnosed with clear cell ovarian cancer two years ago. After multiple chemotherapy regimens, follow-up imaging showed that patient's disease had progression. Hence, further chemotherapy was planned. During premedication drug infusion, she had chills followed by an increase in the body temperature $\left(38.7^{\circ} \mathrm{C}\right)$ in routine chemotherapy practice. She had a central venous catheter (CVC) implanted due to difficulty in drug administration from peripheral vessels nearly two months ago. One set of blood culture (BacT/ALERT aerobic and anaerobic culture media, bioMerieux, France) from CVC was sent to the microbiology laboratory. Her leukocyte count was 5200/ $\mathrm{mm}^{3}$. She was discharged without any medication at the end of chemotherapy. After one week, the patient was admitted with fever and it was seen that blood culture yielded Gram-negative bacilli which were identified as Pantoea spp. by Vitek MS (bio Merieux, France). Antibiotic susceptibility test (performed by Vitek 2, bioMerieux, France) showed the followings: cefuroxime resistant; ampicillin, amikacin, netilmicin, amoxicillin/clavulanic acid, trimethoprim/sulfamethoxazole, cefotaxime, piperacillin/ tazobactam sensitive. She was hospitalized. Her vital findings were as follows: arterial blood pressure: $110 / 70 \mathrm{mmHg}$, pulse: $85 /$ minute and respiratory rate: $18 /$ min. Laboratory findings were as leukocyte: $8250 / \mathrm{mm}^{3}$ and C-reactive protein: 1.26 $\mathrm{mg} / \mathrm{dL}$. There was no erythema in the CVC entry site and on its trace. One set of peripheral and CVC blood culture were performed. Ceftriaxone $2 \mathrm{~g} /$ day was started. Both peripheral and CVC cultures yielded Pantoea spp. Her fever resolved on day 3. However, repeated peripheral and CVC blood cultures on day 6

Cite this article as: Özsoy Kayaokay E, Bulut G, Aydemir Ş, Uslu R, Sipahi OR. Central Line-associated Pantoea spp. Bacteremia and Solid Organ Malignancy: A Report of Two Cases. Mediterr J Infect Microb Antimicrob. 2018;7:13. 
and 11 of ceftriaxone, still yielded Pantoae spp. and coagulasenegative staphylococci. Afterwards CVC was removed and gentamicin was added to ceftriaxone treatment for seven days. Control blood cultures performed on day 16 of ceftriaxone were sterile. She was discharged 21 days after admission. There was no reinfection or relapse during the ten-month follow-up.

The second patient was a 33-year-old female, who was diagnosed with gastric cancer two-months ago. A CVC was implanted for neoadjuvant chemotherapy. After two doses of chemotherapy on day 28 of CVC, she had chills followed by an increase in the body temperature $\left(39.9^{\circ} \mathrm{C}\right)$. One set of blood culture from CVC was sent to the microbiology laboratory. Her arterial blood pressure was $130 / 80 \mathrm{mmHg}$, pulse was $76 /$ minute, and respiratory rate was $16 / \mathrm{min}$. Laboratory investigation revealed blood leukocytes: 5190/mm3 ${ }^{3}$ CRP: $5.33 \mathrm{mg} / \mathrm{dL}$, procalcitonin: $11.6 \mathrm{mg} / \mathrm{dL}$, and erythrocyte sedimentation rate: $17 \mathrm{~mm} / \mathrm{h}$. Empirical ceftazidime $3 \mathrm{~g} /$ day and teicoplanin $800 \mathrm{mg} /$ day were started. One set of peripheral and CVC blood cultures yielded Gram-negative bacilli which were identified as Pantoea dispersa by Vitek MS (bio Merieux, France). Antimicrobial susceptibility test performed and evaluated according to EUCAST ${ }^{[2]}$, resulted as cefuroxime and ampicillin resistant; gentamicin, ciprofloxacin, trimethoprim/sulfamethoxazole, ceftriaxone and piperacillin/ tazobactam sensitive. The catheter was removed due to port catheter infection and was sent for bacteriological culture. Catheter cultures and control blood cultures were sterile. There was no reinfection or relapse during the five-month follow-up.

Globally, the frequency of intravenous catheter use is increasing day by day. In the United States, nearly 150 million intravenous catheters are implanted for intravenous fluids, medications, blood and blood products, parenteral nutrition, monitoring the hemodynamic status or hemodialysis each year ${ }^{[3]}$. As there is an increase in the frequency of catheterization, there is also an increase in catheter-related infections. Catheterrelated infections may manifest with systemic symptoms, such as fever, chills and/or erythema, swelling, and erythema on catheter entry site or trace. However, the presented cases had only chills and fever ${ }^{[4]}$. Catheter-related infection and CRBSI diagnosis require clinical findings as well as aerobic, anaerobic, mycological catheter blood cultures. In the presented cases, CRBSI was diagnosed with concomitant positivity of blood and catheter cultures (catheter culture being positive previously). However, lack of paired peripheral and CVC cultures in some sampling episodes during clinical course causes problems in requesting both peripheral and $\mathrm{CVC}$ cultures in such cases ${ }^{[5]}$. Only a limited number of clinical cases with bacteria belonging to Pantoae spp. have been reported. There is a report in which $P$. agglomerans was isolated from blood cultures of five patients from oncology departments within three months. All patients had CVC and also there was no evidence of any other focus of infection ${ }^{[5]}$. Since we could not perform surveillance cultures, it is not easy to comment about the possible entrance site of the bacteria. There was a two-month gap between the presented cases. However, there was no Pantoae spp. infection during the follow-up period until December 2017.

In conclusion, these two cases suggest the importance of bacteriological sampling and improved culture and identification systems in the diagnosis of CVC infections as well as importance of CVC removal in the management.

\section{Ethics}

Informed Consent: The consent is not needed for this submission. Peer-review: Externally and internally peer-reviewed.

\section{Authorship Contributions}

Surgical and Medical Practices: S..A., R.U., O.R.S., Concept: O.R.S., Design: O.R.S., E.Ö.K., Data Collection or Processing: E.Ö.K., Analysis or Interpretation: Ş.A., Literature Search: E.Ö.K., G.B., Writing: E.Ö.K., O.R.S.

Conflict of Interest: No conflict of interest was declared by the authors.

Financial Disclosure: The authors declared that this study received no financial support.

\section{References}

1. Sengupta M, Banerjee S, Das NK, Guchhait P, Misra S. Early Onset neonatal septicaemia caused by Pantoea agg/omerans. J Clin Diagn Res. 2016;10:1-2.

2. European Committee on Antimicrobial Susceptibility Testing Breakpoint tables for interpretation of MICs and zone diameters. Version 6.0, valid from 2016-01-01. Available from: http://www.eucast.org/fileadmin/src/media/ PDFs/EUCAST_files/Breakpoint_tables/v_8.0_Breakpoint_Tables.pdf

3. Maki DG, Mermel LA. Infections due to infusion therapy. In: Bennett JV, Brachman PS (eds). Hospital infections. Philadelphia: Lippincott-Raven, 1998:689-72.

4. O'Grady NP, Alexander M, Burns LA, Dellinger EP, Garland J, Heard SO, Lipsett PA, Masur H, Mermel LA, Pearson ML, Raad II, Randolph AG, Rupp ME, Saint SS; Healthcare Infection Control Practices Advisory Committee (HICPAC). Guidelines for the Prevention of Intravascular Catheter-related Infections. Clin Infect Dis. 2011;52:162-193.

5. Ulusoy S, Akan H, Arat M, Baskan S, Bavbek S, Çakar N, Çetinkaya Şardan Y, Somer A, Şimşek Yavuz S. Damar içi katater infeksiyonlarının önlenmesi kılavuzu. Hastane İnfeksiyonları Dergisi. 2005;9(Özel Sayı 1):1-32. 